\title{
The Protective Antigen of a Highly Immunogenic Strain of Clostridium chauvoei Including an Evaluation of Its Flagella as a Protective Antigen
}

\author{
By H. M. CHANDLER AND J. GULASEKHARAM \\ Commonwealth Serum Laboratories, Parkville, Victoria, 3052, Australia
}

(Received I April I974)

SUMMARY

Evidence suggesting that the flagella of the highly immunogenic Clostridium chauvoei, strain $\mathrm{CH}_{3}$, may be important in stimulating protective immunity was studied by preparing a pure flagellar suspension from the organism and comparing the protective antigenicity of the flagellar suspension and deflagellated cells. The protective antigenicity of strain $\mathrm{CH}_{3}$ was not of flagellar origin, but due to a heat labile, $\mathrm{pH}$ sensitive, non-agglutinogenic somatic antigen.

\section{INTRODUCTION}

Clostridium chauvoei causes Blackleg, a fatal disease of sheep and cattle. In many countries this is an economically important disease and animal vaccination is commonly practised. Unlike other clostridial vaccines, which are toxoids, Blackleg vaccines are generally prepared from formalinized whole culture (Smith \& Holdeman, I968).

The vegetative cells of $C$. chauvoei possess two known agglutinogens, a heat stable somatic $\mathrm{O}$ antigen common to all strains, and a heat labile flagellar $\mathrm{H}$ antigen of which there are two types (Moussa, I959).

Chandler \& Gulasekharam (I970) reported a number of differences between a highly protective strain of $C$. chauvoei, strain $\mathrm{CH}_{3}$, and a number of less protective strains. Serologically, strain $\mathrm{CH}_{3}$ was distinguished from the other strains by its flagellar antigen, which in our experiments was shared only by the virulent challenge strain, $\mathrm{CH} 4$, used in the animal protection tests.

We now report an investigation of the properties of the protective antigen of strain $\mathrm{CH}_{3}$, some further evidence of an apparent association between the flagellar antigen and protection, the preparation of a pure flagellar suspension, and the comparison of this suspension and the deflagellated cells for protective antigenicity.

\section{METHODS}

Organisms. The following strains of $C$. chauvoei were used: $\mathrm{CH}_{3}$, a highly immunogenic (protective) strain; $\mathrm{CHI}$ and $\mathrm{CH} 2$, relatively poorly immunogenic strains; and $\mathrm{CH}_{4}$, a highly virulent strain used for challenging guinea pigs in the active immunization protection tests. Other details about these strains have been reported (Chandler \& Gulasekharam, 1970).

Cultural method. The organisms were grown at $37^{\circ} \mathrm{C}$ under conditions of controlled $\mathrm{pH}(6.5$ to 7$)$ and half-hourly glucose feed in stirred fermentor vessels containing 31 digest broth. Except where otherwise specified, the cultures were terminated when a total of $2 \%$ 
glucose had been used. The bacteria were removed from the culture by centrifuging at $23000 \mathrm{~g}$ for $20 \mathrm{~min}$.

Vaccines. Dilutions of bacterial suspension or derivative were prepared in normal saline, I $\% \mathrm{AlCl}_{3} \cdot 6 \mathrm{H}_{2} \mathrm{O}$ added, and the $\mathrm{pH}$ of the mixture immediately adjusted to $\mathrm{pH} 6.5$ with $5 \mathrm{M}-\mathrm{NaOH}$. Thiomersal $(0.0 \mathrm{I} \%, \mathrm{w} / \mathrm{v})$ was used in the vaccines as a preservative.

Protection tests. Guinea pigs of 300 to $350 \mathrm{~g}$ weight were given two subcutaneous injections of vaccine, 3 weeks apart, and challenged intramuscularly after a further ro days. The challenge used was a 100 lethal dose calcium chloride-activated spore suspension of the challenge strain $\mathrm{CH}_{4}$ (Chandler \& Gulasekharam, 1970). In every protection test, control unvaccinated guinea pigs were included. These always died within $36 \mathrm{~h}$ of challenge. Vaccinated animals surviving 5 days after challenge were considered to be fully protected.

Rabbit immunization. All rabbits to be used for dosing with antigen were bled and found to be negative for the presence of agglutinins before use. Successive doses of $0.2,0.4,0.8,1.6$ and $3.2 \mathrm{ml}$ of the relevant antigen were given intravenously at 2 to 4 day intervals over a period of $2 \frac{1}{2}$ weeks. The rabbits were then bled by cardiac puncture 7 days after the final injection and the serum separated and stored at $-20^{\circ} \mathrm{C}$.

Agglutination tests. Details of the test are described by Chandler \& Gulasekharam (1970). As before, $\mathrm{H}$ antigen was prepared from a formalinized cell suspension, $\mathrm{O}$ antigen from boiled cells. Serial twofold dilutions of serum were mixed with a standard amount of agglutinating antigen suspension and the end point was read as the last tube showing $75 \%$ clearing.

The titres reported represent the reciprocal of the final serum dilution showing this end point.

Determination of the distribution and heat stability of $\mathrm{CH}_{3}$ strain-protective antigen in culture. A portion of culture was boiled for $2 \mathrm{~h}$, centrifuged, and the boiled organisms were separated from the boiled culture supernatant. The boiled organisms were then reconstituted to their original volume using saline containing $0.4 \%(\mathrm{v} / \mathrm{v})$ formalin. The protective antigenicity of these two culture fractions was then compared with equivalent control fractions in which the supernatant of a live culture was separated from the cells by centrifuging, and the cells were then killed by resuspension in $0.4 \%(\mathrm{v} / \mathrm{v})$ formol saline.

Each fraction was examined under the electron microscope and then prepared as a vaccine for protection testing.

Estimation of the pH stability of the protective antigen. Portions of freshly grown exponential-phase culture were centrifuged, the bacteria resuspended to their original volume in $0.9 \%(\mathrm{w} / \mathrm{v}) \mathrm{NaCl}$ and exposed to the desired $\mathrm{pH}$ by using $0.2 \mathrm{M}-\mathrm{HCl}$ or $5 \mathrm{M}-\mathrm{NaOH}$ added from a burette to the constantly stirred suspensions. After exactly $30 \mathrm{~min}$ at $37^{\circ} \mathrm{C}$, the $\mathrm{pH}$ was re-adjusted to $6 \cdot 1$ with $\mathrm{NaOH}$ or $\mathrm{HCl}$ and $0.4 \%(\mathrm{v} / \mathrm{v})$ formalin added. The cellular appearance was then assessed by electron microscopy.

The suspensions were adjusted with saline to the same Burroughs Wellcome Opacity Tube density, before preparing them as vaccines for protection testing.

Estimation of the heat stability of the protective antigen. Portions of cells in saline were each treated at $37,55,70,85$ or $100{ }^{\circ} \mathrm{C}$ in a water bath for $30 \mathrm{~min}$ and immediately cooled to $10{ }^{\circ} \mathrm{C}$. The appearance of cells from each temperature treatment was then assessed under the electron microscope.

Formalin $(0.4 \%, \mathrm{v} / \mathrm{v})$ was added to each portion as a preservative and later each was prepared as a vaccine for protection testing.

Preparation of pure flagellar suspensions. A preliminary note on this method has already been published (Chandler \& Gulasekharam, I97I). A more detailed description is now given. 
After $2 \mathrm{~h}$ of an exponential growth phase normally lasting $8 \mathrm{~h}$, fermentor cultures were blended for $3 \mathrm{~min}$ in a water-cooled Waring blendor and then dispersed by vibromixing for $3 \mathrm{~min}$ in ten times the culture volume of a solution containing $0.4 \%(\mathrm{w} / \mathrm{v}) \mathrm{NaCl}, 0.02 \%$ $(\mathrm{w} / \mathrm{v})$ sodium dodecyl sulphate and $0.0 \mathrm{r} \%(\mathrm{w} / \mathrm{v})$ thiomersal.

The deflagellated cells were then removed by centrifuging at $16000 \mathrm{~g}$ for $20 \mathrm{~min}$ and the flagella recovered from the supernatant by filtration through a Millipore membrane filter $(0.22 \mu \mathrm{m}$ pore size). The flagella were resuspended from the surface of the membrane into $0.4 \%$ saline by gently rubbing the surface of the membrane with a curved glass rod.

This crude flagellar suspension was purified by enzyme digestion for $3 \mathrm{~h}$ at $37^{\circ} \mathrm{C}$ with I $\mathrm{mg}$ trypsin (BDH; laboratory reagent) $/ \mathrm{ml}$ and $0.5 \mathrm{mg}$ ribonuclease (Boehringer Mannheim $\mathrm{GmbH}$; analytical reagent)/ml in $0.05 \mathrm{M}$-phosphate buffer, $\mathrm{pH} 7.6$. Final purification was then achieved by equilibrium density gradient centrifugation. The flagellar suspension was mixed with caesium chloride to give a final density of $\mathrm{I} \cdot 3 \mathrm{~g} / \mathrm{cm}^{3}$ and centrifuged in a swinging bucket rotor at $182000 \mathrm{~g}$ for $20 \mathrm{~h}$.

The flagella, free of any visible contaminants, formed a dense white band in the central region of the centrifuge tube. This band was then recovered and the $\mathrm{CsCl}$ removed by filtration through an Amicon Diaflo PM to ultrafiltration membrane. The flagella retained in the ultrafilter were then resuspended in distilled water, dispensed into ampoules and freeze-dried until required. One litre of culture yielded approximately $900 \mathrm{mg}$ of flagella.

\section{RESULTS}

\section{Distribution and heat stability of the protective antigen in cultures}

Table I indicates that the main protective antigen of strain $\mathrm{CH}_{3}$ is heat labile and predominantly cellular; only a comparatively small amount of cell-free protective antigen, which was completely heat labile, was detected in the culture supernatant. Boiling of the bacteria for $2 \mathrm{~h}$ caused the disappearance of their flagella as seen in the electron microscope and the destruction of most of the cellular protective antigen. In all our experiments, boiled cells $(\mathrm{O}$ antigen) have retained a low level of protective antigenicity, indicating the presence of a minor heat-stable protective antigen.

To determine if strain $\mathrm{CH}_{3}$ and the challenge strain $\mathrm{CH}_{4}$ share a heat-labile protective antigen in addition to the thermostable, but much less protective, $O$ antigen which is common to all strains, cultures of strains $\mathrm{CH}_{3}, \mathrm{CH} 2, \mathrm{CHI}$ and the challenge strain $\mathrm{CH}_{4}$ were adjusted to the same cell density and their protective potency tested before and after boiling for $2 \mathrm{~h}$. The results (Table 2) show that strains $\mathrm{CH}_{3}$ and $\mathrm{CH}_{4}$ have a heat-labile protective antigen in addition to the heat-stable, but poorly protective, $\mathrm{O}$ antigen shared by all strains.

\section{Effect of various temperatures on the protective antigen of strain $\mathrm{CH} 3$ cells}

The effect of temperature on the protective antigen and the flagellar structure is recorded in Table 3. Heating at $55{ }^{\circ} \mathrm{C}$ for $30 \mathrm{~min}$ caused some destruction of the heat-labile protective antigen; total destruction was achieved after $30 \mathrm{~min}$ at $85^{\circ} \mathrm{C}$, leaving a heat-stable protective antigen only.

When the cells from these treatments were negatively stained and examined under the electron microscope, the flagella of the control cells, i.e. those treated at $37^{\circ} \mathrm{C}$, were long and sinusoidal, with some flagella still attached to the cells. After heating at $55{ }^{\circ} \mathrm{C}$, very few flagella were attached to the cells, the majority appearing shorter and aggregated into circles and coils. Heating at $70^{\circ} \mathrm{C}$ destroyed all but a few short pieces of the flagella, total destruction being achieved after $30 \mathrm{~min}$ at $85^{\circ} \mathrm{C}$. 
Table I. Distribution and heat stability of $\mathrm{CH} 3$ strain protective antigen in culture

\begin{tabular}{|c|c|c|}
\hline \multicolumn{2}{|c|}{ Vaccination of guinea pigs } & \multirow[b]{2}{*}{$\begin{array}{l}\text { Survivors after } 5 \text { days/ } \\
\text { total challenged }\end{array}$} \\
\hline Vaccine & $\begin{array}{l}\text { Dilution of culture } \\
\text { used in vaccine }\end{array}$ & \\
\hline Cells & $\begin{array}{l}1 / 16 \\
1 / 32 \\
1 / 64 \\
1 / 128\end{array}$ & $\begin{array}{l}4 / 4 \\
4 / 4 \\
4 / 4 \\
2 / 4\end{array}$ \\
\hline Boiled cells (boiled $2 \mathrm{~h}$ ) & $\begin{array}{l}\mathrm{I} / 2 \\
\mathrm{I} / 4 \\
\mathrm{I} / 8 \\
\mathrm{I} / \mathrm{I} 6\end{array}$ & $\begin{array}{l}3 / 4 \\
\mathrm{I} / 4 \\
0 / 4 \\
0 / 4\end{array}$ \\
\hline Supernatant of live culture & $\begin{array}{l}I / 8 \\
1 / 16 \\
1 / 32 \\
1 / 64\end{array}$ & $\begin{array}{l}3 / 4 \\
2 / 4 \\
0 / 4 \\
0 / 4\end{array}$ \\
\hline $\begin{array}{l}\text { Supernatant of boiled culture } \\
\text { (boiled } 2 \mathrm{~h} \text { ) }\end{array}$ & $\begin{array}{l}\mathrm{I} / 2 \\
\mathrm{I} / 4\end{array}$ & $\begin{array}{l}0 / 4 \\
0 / 4\end{array}$ \\
\hline
\end{tabular}

Guinea pigs were given two subcutaneous doses of $2 \mathrm{ml} \mathrm{Al-adjuvant} \mathrm{vaccine,} 3$ weeks apart, and challenged after 2 weeks with $\mathrm{LD}_{100} \mathrm{CaCl}_{2}$ activated spore suspension of challenge strain, $\mathrm{CH}_{4}$.

Table 2. Heat stability of the protective antigen of four strains of C. chauvoei

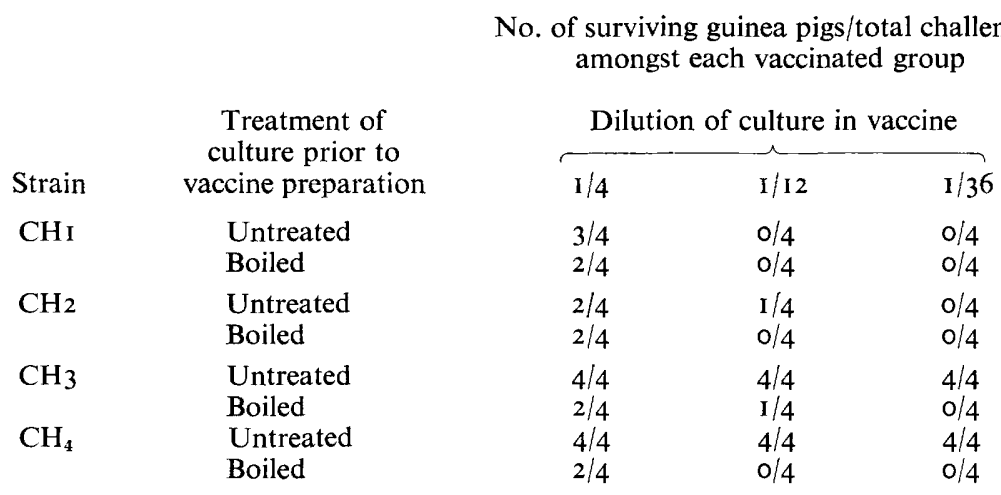

For vaccination procedure, see legend to Table $\mathrm{I}$.

When the cells from these different heat treatments were used to immunize rabbits, the resulting $\mathrm{H}$ titres reflected the observed loss of flagellar structure.

\section{Effect of $\mathrm{pH}$ on the protective antigen of Clostridium chauvoei strain $\mathrm{CH} 3$}

The effect of $\mathrm{pH}$ on the protective antigen and flagellar structure of strain $\mathrm{CH}_{3}$ is shown in Table 4. Most of the protective antigen is destroyed within the $\mathrm{pH}$ ranges of 3 to 4.5 and Io to 12 , the same ranges in which destruction of the flagellar structure occurred. Cells which had been deflagellated by high or low $\mathrm{pH}$ elicited no $\mathrm{H}$ antibody titre when used to immunize rabbits, but gave an $\mathrm{O}$ titre similar to that stimulated by live or boiled cells.

\section{Preparation of pure flagellar suspensions from strain $\mathrm{CH} 3$}

A modification of the usual methods of flagellar suspension preparation was required because of the tendency of the cells to become enmeshed in a network of aggregated flagella, 
Table 3. Effect of temperature on the protective antigen of cells of strain $\mathrm{CH}_{3}$

$$
\text { No. of surviving guinea pigs/total challenged }
$$
amongst each vaccinated group

\begin{tabular}{|c|c|c|c|c|c|c|c|}
\hline \multirow{2}{*}{$\begin{array}{l}\text { Heat treatment } \\
\text { of cells } \\
\left({ }^{\circ} \mathrm{C}\right)\end{array}$} & \multicolumn{5}{|c|}{ Dilution of cell suspension in vaccine } & \multirow{2}{*}{$\begin{array}{c}\mathrm{H} \text { titre } \\
\text { of rabbit } \\
\text { antiserum }\end{array}$} & \multirow{2}{*}{$\begin{array}{l}\text { Flagella } \\
\text { appearances }\end{array}$} \\
\hline & $1 / 4$ & $I / 8$ & $1 / 16$ & $1 / 32$ & $1 / 64$ & & \\
\hline $\begin{array}{c}37 \\
\text { (control cells) }\end{array}$ & - & $4 / 4$ & $4 / 4$ & $4 / 4$ & $4 / 4$ & 2560 & $\begin{array}{l}\text { Typically long and } \\
\text { sinusoidal }\end{array}$ \\
\hline 55 & $4 / 4$ & $3 / 4$ & $2 / 4$ & $1 / 4$ & - & 640 & $\begin{array}{l}\text { Atypical, formed } \\
\text { closed circles and } \\
\text { loops }\end{array}$ \\
\hline 70 & $3 / 4$ & $3 / 4$ & $2 / 4$ & $2 / 4$ & - & 320 & $\begin{array}{l}\text { No intact flagella } \\
\text { visible. A few } \\
\text { short pieces only }\end{array}$ \\
\hline 85 & $3 / 4$ & $0 / 4$ & $\mathrm{I} / 4$ & $0 / 4$ & - & $<20$ & No flagella visible \\
\hline 100 & $2 / 4$ & $2 / 4$ & $0 / 4$ & $0 / 4$ & - & $<20$ & No flagella visible \\
\hline
\end{tabular}

For vaccination procedure, see legend to Table $\mathrm{I}$.

Table 4. Effect of $\mathrm{pH}$ on the protective antigen of cells of strain $\mathrm{CH} 3$

No. of surviving guinea pigs/total challenged amongst each vaccinated group

pH at which cells treated<smiles>[In]I</smiles>

$\begin{array}{cc}\text { Io } & - \\ 6 & - \\ \begin{array}{c}\text { (control cells) } \\ 4 \cdot 2\end{array} & - \\ 3 \cdot 8 & - \\ 3 \cdot 4 & - \\ 3 \cdot 0 & 2 / 4 \\ 2 \cdot 0 & 3 / 4 \\ \text { Boiled cells } & 2 / 4\end{array}$

Dilutions of cell suspension in vaccine

\begin{tabular}{|c|c|c|c|c|c|}
\hline $\mathrm{I} / 4$ & $\mathrm{I} / 8$ & $I / 16$ & $1 / 32$ & $1 / 64$ & in electron microscope \\
\hline $3 / 4$ & $1 / 4$ & $0 / 4$ & $0 / 4$ & - & No flagella \\
\hline- & $3 / 4$ & $1 / 4$ & $0 / 4$ & $0 / 4$ & $\begin{array}{l}\text { Some flagella on cells and } \\
\text { some free }\end{array}$ \\
\hline - & $4 / 4$ & $4 / 4$ & $3 / 4$ & $4 / 4$ & $\begin{array}{l}\text { Flagella of normal appearance } \\
\text { and attached to cells }\end{array}$ \\
\hline 一 & $4 / 4$ & $4 / 4$ & $4 / 4$ & $3 / 4$ & $\begin{array}{l}\text { Flagella of normal appearance } \\
\text { and attached to cells }\end{array}$ \\
\hline 一 & $4 / 4$ & $4 / 4$ & $3 / 4$ & $1 / 4$ & $\begin{array}{l}\text { Flagella of normal appearance } \\
\text { and attached to cells }\end{array}$ \\
\hline 一 & $4 / 4$ & $3 / 4$ & $2 / 4$ & $3 / 4$ & $\begin{array}{l}\text { Free flagella, none attached } \\
\text { to cells }\end{array}$ \\
\hline - & $2 / 4$ & $3 / 4$ & $2 / 4$ & $0 / 4$ & $\begin{array}{l}\text { A few short pieces of flagella } \\
\text { only }\end{array}$ \\
\hline $2 / 4$ & $\mathrm{I} / 4$ & $0 / 4$ & $0 / 4$ & - & No flagella \\
\hline $3 / 4$ & $2 / 4$ & $0 / 4$ & $0 / 4$ & - & No flagella \\
\hline $2 / 4$ & $\mathrm{I} / 4$ & $0 / 4$ & $0 / 4$ & - & No flagella \\
\hline
\end{tabular}

For vaccination procedure, see legend to Table I.

thus hindering the separation of deflagellated cells and flagella by differential centrifugation. This difficulty was overcome by dispersing the flagella and the cells in ten times the culture volume of a medium found to cause minimal flagellar aggregation. The cells could then be centrifuged, allowing recovery of the flagella from the supernatant on the surface of a Millipore membrane filter. This crude flagellar suspension was then further purified by enzymic digestion and equilibrium density gradient centrifugation.

As reported by Chandler \& Gulasekharam (197I), flagella prepared in this way were free from any visible trace of contamination when examined under the electron microscope, and when used to immunize rabbits stimulated a high $\mathrm{H}$ agglutinin titre of $5 \mathrm{I} 20$ with no detectable $\mathrm{O}$ response. No flagella were visible on the deflagellated cells and these cells failed to 
Table 5. Estimation of the protective antigenicity of the flagella suspension

No. of surviving guinea pigs/total challenged amongst each vaccinated group

Dilution of cell or flagella suspension in vaccine

$\begin{array}{llllllll}\mathrm{I} / \mathrm{I} & \mathrm{I} / 2 & \mathrm{I} / 4 & \mathrm{I} / 8 & \mathrm{I} / \mathrm{I} 6 & \mathrm{I} / 32 & \mathrm{I} / 64 & \mathrm{I} / \mathrm{I} 28 \mathrm{I} / 256\end{array}$

Flagella

( $2 \mathrm{mg} / \mathrm{ml})$

Control cells

Deflagellated

cells

Boiled cells

Flagella plus

boiled cells
Pooled guinea pig serum* titre against challenge strain antigens, 2 days before challenge

$\begin{array}{ll}\overbrace{\mathrm{H}} \mathrm{O} \\ 2560 & <20 \\ 2560 & <20 \\ <20 & <20 \\ <20 & <20 \\ 2560 & <20\end{array}$

For vaccination procedure, see legend to Table $\mathbf{I}$.

* Serum from guinea pigs immunized at lowest vaccine dilution.

react with a high titre anti-flagella $(\mathrm{H})$ serum. In rabbits, the deflagellated cells stimulated only a very low $\mathrm{H}$ titre of 20 , compared with a titre of 2560 produced by a control cell suspension of equivalent density.

\section{Estimation of the protective antigenicity of the flagellar suspension}

Flagellar vaccines were formulated from dilutions of a stock suspension of $2 \mathrm{mg}$ flagella/ $\mathrm{ml}$ - this being well in excess of (about double) the flagellar concentration in the original culture. The protective antigenicity of these vaccines was compared with that of vaccines prepared from equivalent concentrations of control cells, deflagellated cells and boiled cells. To determine if both $\mathrm{O}$ and $\mathrm{H}$ antigens were required for protection, a mixture of flagella and boiled cells was also tested. Two days before challenge, guinea pigs immunized at the lowest dilution used for vaccine formulation were bled by cardiac puncture $(2 \mathrm{ml}$ of blood from each), the group sera pooled and the agglutinin titres of the sera against the challenge strain antigens tested. The results (Table 5) show that most of the protective antigen was retained by the deflagellated cells which, while stimulating a high level of protective antibody, produced no detectable $\mathrm{H}$ response. Conversely, the flagellar antigen stimulated a high $\mathrm{H}$ antibody response but produced only a minimal level of protection.

The failure to detect any $\mathrm{O}$ agglutinin response in immunized guinea pig sera has been noted previously (Chandler \& Gulasekharam, I970).

\section{DISCUSSION}

Unlike other clostridial infections in which antitoxic immunity plays the predominant role in protection, protective immunity against $C$. chauvoei is generally considered to be anti-bacterial, and to be stimulated by the heat-stable somatic antigen of the organism (Smith \& Holdeman, I968). Some toxin and some protective antigen may be found in the culture filtrate (Mason, 1936; Mason \& Scheuber, 1936; Verpoorte, Joubert \& Jansen, 1966), but there is little definite evidence that antitoxic immunity is important (Smith \& Holdeman, I968).

The superior immunity produced by strain $\mathrm{CH}_{3}$ was not accounted for by a greatly 
increased toxin production (Chandler \& Gulasekharam, 1970) and we have now shown that most of the protective antigen is cell-associated. Strain $\mathrm{CH} 3$ and the challenge strain $\mathrm{CH}_{4}$ possess a highly immunogenic heat-labile protective antigen, in addition to the heatstable $\mathrm{O}$ antigen which provided a relatively low level of protective immunity in all strains tested.

The heat lability and instability to relatively mild extremes of $\mathrm{pH}$ of this additional protective antigen were properties shared by the flagellar antigen. As we had noted previously (Chandler \& Gulasekharam, 1970) that strain $\mathrm{CH}_{3}$ and the challenge strain $\mathrm{CH}_{4}$ were distinguished from less protective strains only by their common flagellar antigen type, a pure flagellar suspension from $\mathrm{CH}_{3}$ strain was prepared and tested for protective immunogenicity.

In contrast to the findings of Claus \& Macheak (1972), who noted an apparent correlation between agglutination titres and protective immunity, our tests indicated that this correlation need not apply. In our experiments with guinea pigs, deflagellated cells failed to stimulate any measurable agglutinin response but produced a high level of protective immunity. Conversely, the flagellar suspension was highly agglutinogenic but non-protective.

Therefore, in addition to the heat-stable and relatively less protective $\mathrm{O}$ antigen common to all strains of $C$. chauvoei, strain $\mathrm{CH}_{3}$ possesses a non-agglutinogenic, but highly immunogenic, heat-labile, $\mathrm{pH}$-sensitive somatic protective antigen. It is probable that this antigen is the same or closely related to the heat-labile protective antigen of the challenge strain $\mathrm{CH} 4$.

We thank Mr R. Hamilton for the electron microscopy and Miss D. Pickering and Mrs M. Pase for their excellent technical assistance.

\section{REFERENCES}

Chandler, H. M. \& Gulasekharam, J. (1970). An evaluation of characteristics of Clostridium chauvoei which possibly indicate a highly protective strain. Australian Journal of Experimental Biology and Medical Science 48, 187-197.

Chandler, H. M. \& Gulasekharam, J. (1971). Removal and separation of flagella from cells of Clostridium chauvoei and preparation of a pure flagella suspension. Nature, London 230, I 2 I-I 22.

Claus, K. D. \& MACHEAK, M. E. (1972). Preparation of a Clostridium chauvoei antigen and determination of protective immunity by plate agglutination test. American Journal of Veterinary Research 33, 10451052 .

Mason, J. H. (1936). The toxin of Cl. chauvoei. Onderstepoort Journal of Veterinary Science and Animal Industry 7, 433-482.

Mason, J. H. \& Scheuber, J. R. (1936). The production of immunity to Clostridium chauvoei. Onderstepoort Journal of Veterinary Science and Animal Industry 7, 143-I65.

Moussa, R. S. (1959). Antigenic formulae for Cl. septicum and Cl. chauvoei. Journal of Pathology and Bacteriology 77, 34I-350.

Smith, L. D. S. \& Holdemav, L. V. (1968). The Pathogenic Anaerobic Bacteria. Springfield: Charles C. Thomas.

Verpoorte, J. A., Joubert, F. J. \& JANSEn, B. C. (1966). Studies on the soluble antigen and haemolysin of Cl. chauvoei strain 64. South African Journal of Agricultural Science 9, 153-172. 